\title{
Optic nerve hypoplasia: associations and
} \section{management}

\author{
J Roberts-Harry, S H Green, H E Willshaw
}

\begin{abstract}
Since its first description optic nerve hypoplasia has been identified with increasing frequency, and a range of associated problems have been described. The major neurological and endocrine associations are well established, but those factors that predispose to the development of optic nerve hypoplasia remain unclear. To understand the aetiology of these problems better, and to formulate a management regime, we studied a consecutive series of 40 patients who were divided into three groups. Group $1(n=24)$ had severe bilateral optic nerve hypoplasia; group $2(n=10)$ had mild, bilateral optic nerve hypoplasia; and group $3(n=6)$ had unilateral optic nerve hypoplasia. Previously described aetiological factors (for example, low maternal age or maternal alcohol or drug ingestion) were not present in any of the groups; this removes the need to screen a specific population. It is important that careful neurological and developmental assessments are carried out in children with optic nerve hypoplasia to identify potential disease. The role of imaging is discussed.
\end{abstract}

The diagnosis of optic nerve hypoplasia has been made with increasing frequency since its early descriptions, ${ }^{12}$ and it is no longer considered a rarity. A number of predisposing factors have been described, including maternal anticonvulsant ingestion, ${ }^{3}$ low maternal age, ${ }^{4}$ maternal alcohol or drug abuse, ${ }^{56}$ prenatal intracranial pathology, ${ }^{7}$ etc. In addition a wide range of neurological ${ }^{8}$ and endocrine ${ }^{9}$ associations have been recorded.

In view of this array of associations it is difficult to identify a practical and appropriate management regime for each child with optic nerve hypoplasia. In particular, certain clinically important questions have not been directly addressed. Do only those children with severe optic nerve hypoplasia have neurological and endocrine problems? Do all children require some form of central nervous system imaging? Do positive results from such imaging inevitably presage a clinical deficit?

In order to answer these questions better, we have reviewed a series of 40 children seen at our hospital with optic nerve hypoplasia, and attempted to evaluate the frequency of some recognised associations. We discuss their significance, current concepts of pathogenesis, and formulate a guide to the management of these children.

\section{Patients and methods}

A diagnosis of optic nerve hypoplasia was made or confirmed by one of us (HEW) based on the appearance of a combination of features, the most important of which were (a) a small optic nerve head, (b) a second pigmented ring around the disc, and (c) tortuosity or abnormal origin of the vessels arising from the disc. ${ }^{10}$ Rarely were all features present in any one eye. A detailed history was obtained from the mother in every case, specifically including the obstetric history, a history of smoking, alcohol consumption, or drug ingestion during pregnancy, and a history of problems in the neonatal period. The child's development and growth pattern were recorded and in all bilateral cases, and three unilateral, examination by a paediatric neurologist (SHG) was performed. In addition, most children had computed tomography performed, and, where it was considered appropriate, their endocrine state was investigated and any deficiency treated. Serial visual acuity measurements were taken using tests appropriate for age, and included preferred looking acuities in very young or retarded children.

Results

Of the 40 children included in this study, 34 were bilaterally affected, with 24 considered to have a severe degree of optic nerve hypoplasia, and 10 had relatively minor changes. All children who were severely affected showed pallor of the residual disc tissue. Only six children with strictly unilateral involvement were identified, though one child with bilateral optic nerve hypoplasia had appreciable asymmetry of affect. The difference in number between these groups may well reflect our status as a tertiary referral centre rather than the true distribution of the disorder. The three groups of children are considered separately, and their important clinical features are summarised in tables 1,2 , and 3.

The children with severe, bilateral optic nerve hypoplasia (group 1, $n=24$ ) all presented because of poor vision and roving eye movements. Vision varied between $6 / 36$ and no perception of light with most children showing perception of light only. Of the 24 children, 15 had an identifiable neurological deficit, ranging from global retardation to focal pathology such as epilepsy or hemiparesis. Computed tomography was performed on 20 of this group (of the remaining four, three failed to attend for radiographic examination and one was beyond puberty at the time of presentation with no abnormal neurological signs) and 15 were 
Table 1 Group 1: children with bilateral, severe optic nerve hypoplasia $(n=24)$

\begin{tabular}{|c|c|c|c|c|c|}
\hline $\begin{array}{l}\text { Case } \\
\text { No }\end{array}$ & $\begin{array}{l}\text { Visual } \\
\text { acuity }\end{array}$ & $\begin{array}{l}\text { Neurological } \\
\text { disorders }\end{array}$ & $\begin{array}{l}\text { Endocrinological } \\
\text { disorders }\end{array}$ & $\begin{array}{l}\text { Findings on } \\
\text { computed } \\
\text { tomography }\end{array}$ & Comments \\
\hline $\begin{array}{r}1 \\
2 \\
3 \\
4 \\
5 \\
6 \\
7 \\
8 \\
9 \\
10 \\
11 \\
12 \\
13 \\
14 \\
15\end{array}$ & $\begin{array}{l}1 / 60 \\
\text { PL } \\
\text { PL } \\
\text { PL } \\
\text { PL/HM } \\
\text { PL } \\
\text { PL } \\
\text { PL } \\
2 / 60 \\
3 / 60 \\
\text { PL } \\
3 / 60,6 / 36 \\
6 / 36 \\
\text { PL } \\
\text { NPL } \\
\text { PL } \\
\text { PL } \\
\text { HM } \\
4 / 60 \\
\text { PL } \\
\text { PL } \\
\text { PL } \\
2 / 60 \\
\text { PL }\end{array}$ & $\begin{array}{l}\text { Ataxia } \\
\text { Normal } \\
\text { Normal } \\
\text { Epilepsy } \\
\text { Normal } \\
\text { Retarded } \\
\text { Retarded } \\
\text { Normal } \\
\text { Normal } \\
\text { Normal } \\
\text { Retarded } \\
\text { Retarded } \\
\text { Normal } \\
\text { Hemiparesis } \\
\text { Spasticity/retarded } \\
\text { Spasticity/retarded } \\
\text { Normal } \\
\text { Retarded } \\
\text { Spasticity } \\
\text { Retarded } \\
\text { Fits/retarded } \\
\text { Epilepsy } \\
\text { Normal } \\
\text { Retarded }\end{array}$ & $\begin{array}{l}\text { Normal } \\
\text { Normal } \\
\text { Normal } \\
\text { Panhypopituitarism } \\
\text { Normal } \\
\text { Normal } \\
\text { Normal } \\
\text { Normal } \\
\text { Normal } \\
\text { Normal } \\
\text { Normal } \\
\text { Reduced somatotrophin } \\
\text { Reduced somatotrophin } \\
\text { Normal } \\
\text { Normal } \\
\\
\text { Normal } \\
\text { Normal } \\
\text { Normal } \\
\text { Normal } \\
\text { Hypopituitarism } \\
\text { Normal } \\
\text { Normal } \\
\text { Reduced somatotrophin } \\
\text { Normal }\end{array}$ & $\begin{array}{l}\text { Normal } \\
\text { Not done } \\
\text { Normal } \\
\text { Agenesis corpus collosum } \\
\text { Cortical atrophy } \\
\text { Cortical atrophy } \\
\text { Cortical and cerebellar atrophy } \\
\text { Not done } \\
\text { Normal } \\
\text { Cortical and cerebellar atrophy } \\
\text { Normal } \\
\text { Absence septum pellucidum } \\
\text { Absence septum pellucidum } \\
\text { Porencephaly } \\
\text { Porencephaly/agenesis corpus } \\
\text { collosum } \\
\text { Porencephaly } \\
\text { Agenesis corpus collosum } \\
\text { Porencephaly } \\
\text { Normal } \\
\text { Porencephaly } \\
\text { Not done } \\
\text { Porencephaly } \\
\text { Not done } \\
\text { Cortical atrophy }\end{array}$ & $\begin{array}{l}\mathrm{X} \text { linked albino } \\
\text { Fetal alcohol syndrome } \\
\text { Neonatal hypoglycaemia }\end{array}$ \\
\hline
\end{tabular}

PL, perception of light; NPL, no perception of light; HM, hand movements.

Table 2 Group 2: children with bilateral, mild optic nerve hypoplasia $(n=10)$

\begin{tabular}{|c|c|c|c|c|c|}
\hline $\begin{array}{l}\text { Case } \\
\text { No }\end{array}$ & $\begin{array}{l}\text { Visual } \\
\text { acuity }\end{array}$ & $\begin{array}{l}\text { Neurological } \\
\text { disorders }\end{array}$ & $\begin{array}{l}\text { Endocrinological } \\
\text { disorders }\end{array}$ & $\begin{array}{l}\text { Findings on } \\
\text { computed } \\
\text { tomography }\end{array}$ & Comments \\
\hline $\begin{array}{l}25 \\
26 \\
27 \\
28 \\
29 \\
30 \\
31 \\
32 \\
33 \\
34\end{array}$ & $\begin{array}{l}\text { PL/HM } \\
6 / 9,6 / 6 \\
6 / 12 \\
6 / 12 \\
6 / 18 \\
6 / 6,6 / 18 \\
6 / 12,6 / 6 \\
6 / 12,6 \\
6 / 9 \\
6 / 9\end{array}$ & $\begin{array}{l}\text { Retarded } \\
\text { Hemiparesis } \\
\text { Normal } \\
\text { Normal } \\
\text { Normal } \\
\text { Normal } \\
\text { Retarded } \\
\text { Retarded } \\
\text { Normal } \\
\text { Normal }\end{array}$ & $\begin{array}{l}\text { Normal } \\
\text { Normal } \\
\text { Normal } \\
\text { Normal } \\
\text { Normal } \\
\text { Normal } \\
\text { Normal } \\
\text { Normal } \\
\text { Reduced somatotrophin } \\
\text { Normal }\end{array}$ & $\begin{array}{l}\text { Porencephaly } \\
\text { Dilated lateral ventricle } \\
\text { Enlarged basal cistern } \\
\text { Normal } \\
\text { Dilated ventricles } \\
\text { Normal } \\
\text { Normal } \\
\text { Dilated ventricles } \\
\text { Absence septum pellucidum } \\
\text { Not done }\end{array}$ & Fetal alcohol syndrome \\
\hline
\end{tabular}

PL, perception of light; HM, hand movements.

Table 3 Group 3: children with unilateral optic nerve hypoplasia $(n=6)$

\begin{tabular}{llllll}
\hline $\begin{array}{l}\text { Case } \\
\text { No }\end{array}$ & $\begin{array}{l}\text { Visual } \\
\text { acuity }\end{array}$ & $\begin{array}{l}\text { Neurological } \\
\text { disorders }\end{array}$ & $\begin{array}{l}\text { Endocrinological } \\
\text { disorders }\end{array}$ & $\begin{array}{l}\text { Findings on } \\
\text { computed } \\
\text { tomography }\end{array}$ & Comments \\
\hline 35 & $6 / 9$ & Hemiparesis & Normal & Porencephaly \\
36 & CF & Retarded & Normal & Normal \\
37 & $6 / 12$ & Retarded & Normal & Normal \\
38 & $6 / 60$ & Normal & Normal & Not done \\
39 & $6 / 12$ & Normal & Normal & Not done \\
40 & $6 / 9$ & Normal & & \\
\hline
\end{tabular}

$\mathrm{CF}$, counting fingers.

abnormal. The range of abnormalities found on computed tomography is shown in table 1 , but it should be noted that three of the five children with midline abnormalities had endocrine deficiency, and eight of the 10 children with nonmidline pathology had a neurological deficit. Conversely three of the five children with entirely normal scans also had clinical evidence of a neurological deficit.

The mean maternal age in the children with severe, bilateral optic nerve hypoplasia was $26 \cdot 8$ years, the mean paternal age $27 \cdot 6$ years, and only one couple were below 20 at the time of their child's birth (two mothers and two fathers were over 30 ). No mother took anticonvulsants, two took antiemetics in the first trimester, and one regularly took antihistamine:. One mother was alcoholic and her daughter showed the other dysmorphic features of the fetal alcohol syndrome. ${ }^{11}$ Only three mothers smoked during pregnancy, and four mothers suffered threatened abortions during the first trimester. One child in this group had severe neonatal hypoglycaemia.

A similar analysis of those children with less severe bilateral optic nerve hypoplasia (group 2, $\mathrm{n}=10$ ) showed that six children had abnormal computed tomograms. One child with midline developmental abnormalities was deficient in growth hormone, and three of the children with other abnormalities found on computed tomography had neurological damage. In this group the mean maternal age was $27 \cdot 2$ with no mothers under 20 or over 32 ; the mean paternal 
age was 31.6 One mother in this group was alcoholic, and one mother was addicted to a proprietary cough medicine. There was no history of smoking or other drug ingestion among the remaining mothers.

In the children with unilateral optic nerve hypoplasia (group 3, $n=6$ ), three children had serious neurological abnormalities, though in only one was this predicted by an abnormal computed tomogram. In these children the optic nerve hypoplasia was a chance finding in two, and in the remainder was found after presentation with strabismus or amblyopia.

\section{Discussion}

The different entities reported to be associated with optic nerve hypoplasia appear to be legion, and only by reviewing large groups of patients is it possible to avoid false impressions gained as a result of biased ascertainment. This series, because of the nature of our hospital, is certainly biased but considered along with other large series ${ }^{12} 13$ allows us to evaluate critically some of the associations previously described.

After the original report in $1978^{3}$ no children have been recorded in whom maternal anticonvulsant ingestion has been a predisposing feature. Furthermore, review of an epilepsy service showed no affected mothers having visually handicapped children (J A Finnegan, personal communication). While this does not rule out mild optic nerve hypoplasia, it must now be considered that this described association is probably an unusual artefact of recruitment. Though phenytoin in particular is known to be teratogenic, ${ }^{14}$ the explanation of the 1978 findings remains obscure. Similarly, though the largest series published did not address the question of maternal or paternal age, ${ }^{12}$ there is no evidence in this group of parents to support the concept of low maternal age as a predisposing factor. The other reported links with maternal alcoholism ${ }^{5}$ and maternal drug ingestion ${ }^{6}$ are supported so far as alcoholism is concerned, but it is impossible to draw any conclusions about an association with the ingestion of hallucinogenic drugs. A possible connection with severe neonatal hypoglycaemia has been described, ${ }^{15}$ and one of our children required intravenous glucose in the first three days of life. Though most children with optic nerve hypoplasia give no such history it would certainly be wise to ensure a detailed ophthalmic examination on any neonate with severe hypoglycaemia. There appears, however, to be a large pool of affected children in whom the aetiological agent has not been identified. The pathogenesis of optic nerve hypoplasia remains uncertain, but it is likely that the documented reduction in numbers of ganglion cells in the retina of affected eyes is a secondary rather than a primary event as the other cells derived from the same stem as the ganglion cells are not reduced in number. ${ }^{16}$ Retrograde degeneration of developing axons, which is an established feature of normal optic nerve development, ${ }^{17}$ may well be excessive in these children. Presumably some insult leads to this excessive retrograde degeneration, and experimental evidence has shown that, in the case of alcohol at least, the insult must be delivered in the early weeks of pregnancy. ${ }^{18}$ In animal models the timing of the alcohol infusion to cause optic nerve hypoplasia is critical, and the same work showed that a similar dose in different individuals was capable of leading to a variable severity of affect. The mechanism of alcohol toxicity may well be enhanced degeneration, again supporting this concept of the pathogenesis of human optic nerve hypoplasia.

The incidence of porencephaly in children with optic nerve hypoplasia is worthy of comment. There have been several isolated reports of such an association, including histopathological examination of the eyes and brain, ${ }^{19}$ but generally greater attention has focused on midline pathology. However, analysis of the 93 patients of Skarf and Hoyt and the current series shows porencephaly to be the more common finding on computed tomography. ${ }^{12}$ Porencephaly commonly results from a vascular insult to the developing nervous system, ${ }^{20}$ and Myers found both porencephaly and reduced ganglion cells in the offspring of a monkey suffering partial placental abruption in early pregnancy. ${ }^{21}$ The possibility that some first trimester obstetric event might trigger the central nervous system and optic nerve problems is appealing, but among the total group of 40 patients, only five mothers suffered an identifiable event in the first 10 weeks of pregnancy. This figure would not be remarkable in a group of 40 pregnancies so once again the association must remain speculative.

In the absence of any other recognisable cause, could disease in the central nervous system obstruct the development of normal synaptic connections, or alternatively prevent proper cortical induction of the developing visual pathways? Taylor has argued that the presence of a space occupying lesion (including a porencephalic cyst) may act as a barrier to normal synaptic development, and felt that this mechanism explained his observation of an incidence of associated developmental tumours of the anterior visual pathways. ${ }^{7}$ No child in this series showed evidence of tumour formation, indeed it is an extreme rarity to identify tumour formation in a child where the diagnosis of optic nerve hypoplasia has first been established (as opposed to identifying optic nerve hypoplasia in a child with a known tumour). None the less, it does seem likely that the pathogenesis of optic nerve hypoplasia involves a block to normal visual pathway development, either by some intracranial pathology, or by a vascular insult that simultaneously leads to intracranial pathology.

Like other authors we have identified a high incidence of neurological and endocrine associations. We have not undertaken the major endocrinological assessment previously reported, ${ }^{12}$ four of 24 severely affected children and one of 10 mildly affected, however, showed clinical and biochemical evidence of major hormone deficiency. The incidence of neurological associations is even more striking $(62 \cdot 5 \%$ of group 1 and $40 \%$ in group 2). It is disappointing to find, however, that while both the severity of optic 
nerve hypoplasia and findings on computed tomography are suggestive of neurological problems, neither predicts absolutely. This raises the question of how these children may best be managed at a clinical level. The significant incidence of neurological deficit in children with normal scans (six of the total group of 40), and conversely the incidence of children with abnormal scans but no identifiable neurological problems (five of 40) suggests that while scanning provides information on the likelihood of problems, it is not reliably predictive in any one child. If the risk of developmental visual pathway tumours can be confirmed, then scanning (or ultrasonography in the very young) would be mandatory. If this association is not confirmed then it is our belief that these children can be well managed by careful clinical assessment and prolonged monitoring of growth and development, without recourse to expensive investigations.

1 Sheie HG, Adler FH. Aplasia of the optic nerve. Arch Ophthalmol 1941;26:61-70.

2 Duke-Elder S. Congenital deformities. System of ophthalmology. Normal and abnormal development. London: Kimpton, 1964:671.

3 Hoyt CS, Billson FA. Maternal anticonvulsants and optic nerve hypoplasia. Br $\mathcal{F}$ Ophthalmol 1978;62:3-6.
4 Robinson CG, Conry RF. Maternal age and congenital optic nerve hypoplasia: a possible clue to aetiology. Dev med Child Neurol 1986;28:294-8.

5 Miller M, Israel J, Cuttone J. Fetal alcohol syndrome. $\mathcal{F}$ Pediatr Ophthalmol Strabismus 1984;55:595-8.

6 Hoyt CS. Optic disc anomalies and maternal ingestion of LSD. Fournal of Pediatric Ophthalmology and Strabismus 1978;15:286-9.

7 Taylor D. Congenital tumours of the anterior visual system with dysplasia of the optic discs. Br $\mathcal{F}$ Ophthalmol 1982;66: with dys 63 .

8 Billson FA. The clinical significance of optic nerve hypoplasia. Transactions of the Ophthalmological Society of New Zealand 1973

9 Hoyt WF, Kaplan SL, Grumbach MM, et al. Septo optic dysplasia and pituitary dwarfism. Lancet 1970;i:893-4.

10 Apple DJ, Robb MF, Walsh PM. Congenital anomalies of the optic disc. Surv Ophthalmol 1982;27:3-41.

11 Stromland K. Ocular abnormalities in the foetal alcohol syndrome. Acta Ophthalmol (Copenh) 1985;93:1-50.

12 Skarf B, Hoyt CS. Optic nerve hypoplasia in children. Arch Ophthalmol 1984;102:62-7.

13 Walton DS, Robb RM. Optic nerve hypoplasia: a report of 20 cases. Arch Ophthalmol 1970;84:255-8.

14 Meadow SR. Anticonvulsant drugs and congenital abnormalities. Lancet 1968;ii:1296.

15 Stanhope R, Brook CDG. Neonatal hypoglycaemia: an important early sign of endocrine disorders. BrMed $\mathcal{F} 1985$; 291:728-9.

16 Jerome B, Forster HW. Congenital hypoplasia of the optic nerve. Arch Ophthalmol 1948;39:699-72.

17 Glucksman A. Cell death in normal vertebrate ontogeny. Biological Reviews 1951;26:59-86.

18 Cook CS, Nowotny AZ, Sulik KK. Fetal alcohol syndrome eye malformations in a mouse model. Arch Ophthalmol 1987; 105:1576-81.

19 Mosier MA, Lieberman MF, Green RW, Knox DL. Hypoplasia of the optic nerve. Arch Ophthalmol 1975;76: $1437-42$

20 Friede RL. Developmental neuropathology. New York: Springer-Verlag, 1975.

21 Myers RE. Cystic brain alteration after incomplete placental abruption in monkey. Arch Neurol 1969;21:133-41. 